\title{
AGAMA DAN PENYELENGGARAAN PEMERINTAHAN YANG BAIK
}

Oleb: Amir Faisol*

\section{Abstract}

There are three components to implement a good government. First, government which make conducive law and politic environment: second, private business sector which motivate business fields and prepare occupations field;and third, society which facilitate social-politic interaction and mobilize society participation in economic, social and politic activities. To implement those components, a state caretaker must bold to people mandate and serve their interests and also bold to law supremacy for maintaining a justice and people prosperity. No one be able to implements those components except who bas beart of bearts and commits on its, and also bas bigh quality intelligence, emotional, spiritual in work etbos.

للحصول على النظم الحكومية النازهة لا بد من توفير ثلاثة عناصم.الأول، الحلكومة التي استولى عليها بيئة المياسة والسلطة الرفيعة: والثالني، تشتجيع القطلاع المخاص اللذي يكرك الشركات وإنشاء فرص الأعمال، والثالث، اليختهع المنفتح للحوار لبناء الحياة الإجتماعية والسياسية، وتحريك المتمع للإشتراك في نشاط الإقتصادية، والإجتماعية، والسياسة. ولازم على أجهزة الدولة بأن يتمسك بأمانة الرعية والتوجيه الم خحمة معلحتها، وتقوق السططة والقانون لإعلاء العدالة والرفاهية في البمتمع. لأ حل من أجهزات الدولة يستطيع أن يطبت هذه العناصر إلا وله وجلدان وملتزم بهء وبجانب ذلك، له نحاصة الذكاء العلياء والإنفعالية، والروحانية الرفيعة في جميع الأعمال.

Kata kunci: agama, pemerintah, masyarakat, dan politik

* Penulis adalah Dosen Fakultas Tarbiyah IAIN Sultan Thaha Saifudin, Jambi 


\section{A. Pendabuluan}

Tuntutan reformasi terhadap penyelenggaraan pemerintahan yang baik dan bersih merupakan reaksi terhadap penyelenggaraan pemerintahan pada masa Orde Baru dengan berbagai permasalahannya. Masalah utamamya berkenaan dengan pemusatan kekuasaan pada presiden sebagai kepala pemerintahan dan kepala negara. Hal ini disebabkan karena konstitusi UUD 1945 yang memang menentukan demikian dan tidak berfungsinya lembaga tinggi dan tertinggi negara. Selain itu, tersumbatnya saluran partisipasi rakyat dalam mengawasi dan mengontrol jalannya penyelenggaraan pemerintahan juga menjadi faktor yang mendukungnya. Keinginan untuk memperoleh penyelenggaraan pemerintahan yang baik dan bersih belum dapat terpenuhi. Berbagai kendala bermunculan dalam bentuk gejolak politik, ekonomi, sosial-budaya, hukum, dan bahkan pendidikan. Akhirnya, lahirlah suasana kehidupan tidak menentu yang sangat membahayakan sendi-sendi kehidupan rakyat. ${ }^{1}$

\section{B. Penyelenggaraan Pemerintaban yang Baik}

Menurut Masyarakat Transparansi Indonesia (MTI), good governance berkenaan dengan pemahaman atas prinsip-prinsip yang mendasari penyelenggaraan pemerintahan. Hal ini meliputi:

1. Partisipasi masyarakat dalam menyuarakan aspirasinya untuk pengambilan keputusan yang dilakukan oleh pemerintah;

2. Supremasi hukum yang berintikan keadilan dan pemerataan bagi semua rakyat, termasuk hukum yang berkenaan dengan hak asasi manusia (HAM);

3. Transparansi atas dasar informasi bebas dari tekanan. Seluruh informasi tentang penyelenggaraau pemerintahan maupun kelembagaan harus dapat diakses oleh yang berkepentingan, selain juga harus memadai agar dapat dipantau dan dipahami;

4. Penyelenggaraan pemerintahan yang berorientasi pelayanan bagi kepentingan rakyat. Ini sangat berfungsi dalam menjembatani berbagai kepentingan untuk mencari yang terbaik dengan tujuan terbangunnya suatu konsensus dalam kebijakan dan prosedur;

5. Kesetaraan kehidupan rakyat dalam upaya memperbaiki dan memperoleh kesejahteraan; 
6. Efektivitas dan efisiensi proses penyelenggaraan pemerintahan bagi pemenuhan kebutuhan masyarakat dengan penggunaan sumber daya manusia dan alam yang dimiliki;

7. Akuntabilitas para pengambil keputusan baik oleh pemerintah, badan swasta maupun organisasi kemasyarakatan yang bertanggung jawab terhadap lembaga-lembaga yang berkepentingan;

8. Visi strategis para pemimpin dan masyarakat dalam perspektif ke depan atas penyelenggaraan pemerintahan yang baik dan pemahaman terhadap kompleksitas kehidupan sosial-budaya yang mendasari perspektif tersebut. $^{2}$

Selain itu, good Governance dapat juga diartikan sebagai suatu proses yang mengarahkan terciptanya kekuatan dan kewenangan yang merata dalam seluruh elemen masyarakat untuk mempengaruhi keputusan dan kebijakan yang berkaitan dengan kehidupan publik serta seluruh upaya pembangunan sosial dan ekonomi masyarakat. Oleh karena itu good governance mensyaratkan adanya proses yang berkelanjutan untuk mengakomodasi dan memediasi konflik-konflik kepentingan dalam struktur masyarakat, sehingga dapat memperoleh suatu kesepakatan bersama. ${ }^{3}$

United Nations Development Program (UNDP) merumuskan setidaknya terdapat tiga pihak yang berperan sebagai pelaku dalam good governance, yaitu negara atau pemerintah, sektor usaha šwasta dan masyarakat. Setiap pelaku ini memiliki peranan tersendiri yang berbeda antara yang satu dengan yang lainnya. Secara umum, dalam civil society; pemerintah berperan dalam menciptakan lingkungan politik dan hukum yang kondusif; sektor usaha swasta berperan dalam menggerakkan dunia usaha sehingga dapat menyediakan lapangan pekerjaan dan memberikan pendapatan yang layak; masyarakat berperan dalam memfasilitasi interaksi sosial-politik dan memobilisasi kelompok-kelompok masyarakat untuk berpartisipasi dalam kegiatan perekonomian, sosial dan politik.

Berbeda dengan UNDP di atas, United Nations Economic and Social Commission for Asia and the Pacific, mengartikan penyelenggaraan pemerintahan yang baik (good governance) sebagai sesuatu yang mẹngandung unsur-unsur partisipasi, supremasi hukum, transparansi, responsiveness, adanya

${ }^{2}$ Ibid.

${ }^{3}$ Ardiansyah Samsura (2002), Participatory Planning, Good Govemance, and Civil Society, Forum Pengembangan Partisipasi Masyarakat (FPPM).

${ }^{4}$ Ibid 
konsensus, efektif dan efisien, akuntabilitas, dan strategic vision. ${ }^{5}$ Adapun good governance menurut Rochman Achwan, merupakan paradigma pembangunan paling komprehensif sebagaimana troli yang ditarik oleh tiga ekor kuda, yaitu negara, pasar, dan masyarakat. ${ }^{6}$ Oleh karena itu, salah satu syarat dapat ditegakkannya good governance adalah stabilitas politik yang mengkondisikan kepastian hukum. Selain itu, penyelenggara pemerintahan juga harus mampu membuat komitmen-komitmen yang dapat dipercaya dan mampu meyakinkan sektor swasta bahwa keputusan-keputusan yang diambil tidak akan dicabut karena ketidakpastian politik.

Salah satu konsekuensi negara Indonesia sebagai inegara hukum adalah adanya tiga prinsip dasar yang harus dihormati, yaitu supremasi hukum (supremacy of law), kesetaraan di hadapan hukum (equality before the law), dan penegakan hukum. Kesemuanya harus dijalankan dengan cara-cara yang tidak bertentangan dengan hukum itu sendiri (due process of law). ${ }^{7}$

Administrasi negara sebagai penyelenggaraan negara dalam fungsi pemerintahan (eksekutif), berkaitan langsung dengan kehidupan rakyat. Penertiban, perizinan, dan berbagai pelayanan merupakan tugas dan pekerjaan administrasi negara yang langsung berhubungan dengan rakyat. Oleh karena itu, apabila terjadi penyalahgunaan kekuasaan atau cara-cara bertindak yang tidak memenuhi syarat administrasi negara yang baik akan langsung dirasakan oleh rakyat ataupun orang-orang tertentu sebagai tindakan sewenang-wenang. Bukan hanya itu, lembaga penyelenggara negara yang lain seperti legislatif, sebagai badan pembuat undang-undang, juga dapat melakukan tindakan sewenangwenang, apabila undang-undang tersebut tidak berpihak kepada rakyat. Demikian pula lembaga yudikatif sebagai badan penegak hukum (kekuasaan kehakiman), dapat saja melakukan tindakan sewenang-wenang, yang bukan saja disebabkan oleh hukum yang tidak berdaya. Kesewanang-wenangan itu juga dapat dilakukan oleh lembaga yudikatif dengan berkolaborasi bersama lembaga negara lainnya (eksekutif dan legislatif). Selain itu, kesewenangan lembaga

${ }^{5}$ Sudjadnan Patnohadiningtat (2004), Good Governance dalam Perspektif Diplomasi Kontemporer, Jakarta: Makalah Ceramah di Lemhanas Kelompok Departemen Luar Negeri, 5 Oktober.

'Dadang Solihin (2000), Anti Comption and Good Governance, Jakarta: Makalah dalam Diskusi Mingguan Sekretariat Pengembangan Public Good Governance Bappenas, 24 Agustus.

7 Ismail Sunny (2003), Implikasi Amandemen UUD 1945 Terhadap Sistem Hukum Nasional, Bali: Makalah dalam Seminar Pembangunan Nasional ke-VIII di Bali, tanggal, 14-18 Juli. 
penegak hukum juga dapat terjadi karena penyalahgunaan kekuasaan yang ada pada lembaga ini. ${ }^{8}$

Dengan adanya kemungkinan yang demikian, maka penyelenggara pemerintahan seharusnya commit terhadap tugasnya sebagai pemegang amanah rakyat. Oleh karena itu, penyelenggara pemerintahan juga harus mendahulukan kepentingan rakyat daripada kepentingan pribadi atau kepentingan segolongan orang-orang tertentu. ${ }^{9} \mathrm{Hal}$ ini disebabkan karena pada setiap diadakan pemilihan umum, rakyat selalu berharap agar calon pemimpin yang akan terpilih sebagai pemenang mampu mengemban amanah rakyat dan melaksanakan tugasnya dengan cara yang bersih, berwibawa, dan profesional agar tercapai cita-cita bangsa yang berkeadilan dan sejahtera di bawah naungan dan keridhaan Tuhan. Namun kenyataannya kerap kali berbicara lain, setiap selesai pemilihan umum dan penyelenggara pemerintahan terbentuk, rakyat selalu menemukan kesewenangwenangan. Akhirnya harapan mereka sedikit bercampur cemas serta penuh dengan pertanyaan tentang apakah para pemimpinnya konsisten dan mampu berpegang pada amanah yang telah diberikan dalam melaksanakan tugastugasnya.

\section{Realitas Penyelenggaraan Pemerintaban di Indonesia}

Aspirasi dan cita-cita rakyat Indonesia hingga kini dapat dikatakan belum terwujud. Pemimpin telah bergantian dalam memimpin negara Indonesia. Ada yang semula menjanjikan terwujudnya kehidupan sejahtera, berkeadilan, dan merata, namun yang terjadi sebaliknya, perekonomian semakin terpuruk. Akhirnya kehidupan rakyat sangat terbelakang di hampir semua aspek. Angka kemiskinan dari hari ke hari makin membesar dan rakyat kecil sangat susah untuk mempertahankan kehidupan mereka. Anak-anak Indonesia semakin sulit mendapatkan pendidikan yang layak demi masa depan mereka. Orang tua tidak mampu membiayai kelanjutan pendidikan anak-anaknya karena semakin mahalnya biaya pendidikan dan masih banyak lagi realitas yang serupa.

Hingga saat ini, rakyat masih dapat melihat dan menyaksikan betapa banyaknya para penyelenggara pemerintahan yang terlibat kasus penyelewengan keuangan negara (korupsi). Uang negara yang sebenarnya merupakan kekayaan rakyat miskin dirampas oleh para penguasa. Hal ini masih sering terjadi karena

${ }^{8}$ Bagir Manan (1999), "Good Governance Hindarkan Rakyat dari Tindakan Negara yang Merugikan" dalam Jurnal Transparansi Jakarta.

9 Emil Salim (1999), "Good Governance dan Masyarakat Warga" dalam Jurnal Transparansi, Jakarta. 
penyelenggara pemerintahan tidak memiliki kemampuan untuk menegakkan hukum dan keadilan. Melihat realitas yang demikian, masalah penegakan hukum merupakan sesuatu yang mutlak dan harus diupayakan oleh penyelenggara pemerintahan. Walaupun bangsa Indonesia, sangat mungkin, belum terbiasa berpikir untuk menyelesaikan permasalahan melalui proses hukum, namun penegakan hukum harus selalu diupayakan. Ini sangat mungkin disebabkan terlalu lamanya dan berbelit-belitnya pemberantasan korupsi, kolusi, dan nepotisme di Indonesia. ${ }^{10}$

Bagi rakyat, penyelenggaraan pemerintahan harus dapat memberikan kemudahan dan kepastian hukum. Selain itu, penyelenggaraan pemerintahan yang bersih dalam pelayanan juga menjadi harapan mereka. Hal ini untuk melindungi tindakan yang sewenang-wenang dan tidak adil oleh penyelenggara negara baik atas diri, hak maupun harta benda rakyat. Pelayanan yang memakan waktu dan bertele-tele bukan hanya akan memperlambat laju perekonómian namun juga akan menjadi fungsi "komersial" bagi pemerintah. Oleh karenanya, sampai saat ini masih sering terdengar istilah "uang pelicin" dan istilah-istilah lainnya. ${ }^{11}$

Rasa ketidakadilan dan hilangnya perlindungan hukum bagi semua rakyat semakin mendalam dan meluas. Bila rakyat kecil melanggar hukum pasti akan mendapatkan hukuman, tetapi sebaliknya, bila kasus pelanggaran hukum dilakukan oleh penguasa dan dengan tingkat membahayakan kehidupan dan ekonomi rakyat serta merendahkan martabat bangsa hukum cenderung diperlakukan lunak. Hal ini sangat mengganggu rasa ketidakadilan bagi masyarakat. Pelanggaran hukum oleh penguasa yang semestinya diganjar hukuman lebih berat, malah mendapat hukuman yang ringan, bahkan tidak dihukum sama sekali. Jika pun tidak demikian, kasus pelanggaran hukum oleh penguasa seringkali “menguap” di tengah jalan.

Media elektronik masih sering menayangkan komentar-komentar para elit penguasa yang mengeluh karena adanya kejadian pencurian ataupun kejahatan lain di tengah kehidupan masyarakat serta upaya penanggulangannya. Namun mereka sendiri jarang bahkan tidak pernah mengoreksi dirinya sendiri sebagai pernegang amanah rakyat. Mereka jarang melakukan introspeksi diri tentang pelanggaran hukum yang terjadi di sekitarnya padahal itu juga sangat banyak sekali. Gejala seperti ini sesungguhnya merupakan gambaran dari apa yang telah

${ }^{10}$ Nurcholis Madjid (2000), “Kita Masih Memerlukan Ketegasan Komitmen”, dalam Jurnal Transparansi, Jakarta

- 11 Bagir Manan op. cit. 
terjadi pada mereka sendiri. Niccolo Machiavelli dalam The Discourses III, yang dikutip oleh Andi W. Syahputra mengatakan:

"Mereka yang bicara tentang rakyat bahwa telah menjadi perampok dan penjahat akan menemukan bahwa semua itu terjadi lantaran orang-orang yang memerintah mereka juga memiliki perilaku yang sama". ${ }^{12}$

Lemahnya penegakan hukum membuat rakyat kehilangan kepercayaan terhadap para pemimpinnya. Walaupun ada beberapa pemimpin yang berusaha dengan sekuat tenaga dan pikiran untuk memenuhi cita-cita rakyat, namun kepercayaan tersebut tetap lemah. Penegakan hukum merupakan tolok ukur bagi rakyat untuk menilai apakah pemerintahan yang berkuasa telah bertanggung jawab atas mandat dan kepercayaan yang telah diberikan atau tidak. Amin Rais pernah mengatakan bahwa kekuasaan rakyat adalah hukum paling tinggi dan tidak ada hukum yang lebih tinggi dari kemauan rakyat (Salus Populi Suprem Lex). ${ }^{13}$

Kepemimpinan suatu negara secara esensial merupakan amanah Tuhan. Oleh karena itu, setiap penyelenggara pemerintahan harus bertanggung jawab dan berpegang teguh pada amanah rakyat. Karena merupakan amanah, maka hal itu juga harus dipertanggungjawabkan di hadapan Tuhan sebagai bentuk pengabdian pada-Nya. Dalam filsafat Barat terkenal istilah Vox Populi Vox Dei, yang berarti suara rakyat adalah suara Tuhan. Istilah ini juga berarti bahwa kedaulatan rakyat tidak dapat dikompromikan dengan kepentingan lain karena merupakan perpanjangan dari amanah Tuhan. ${ }^{14}$ Tindakan penyelewengan, seperti korupsi, di Indonesia dalam penelitian lembaga-lembaga dunia menempati posisi tertinggi. Laporan World Economic Forum pada tahun 1999, menunjukkan bahwa Indonesia termasuk salah satu negara yang teburuk di antara 59 negara yang diteliti. ${ }^{15}$ Sedangkan para pelakunya atau koruptor mayoritas berasal dari orang-orang yang memiliki power ${ }^{16}$ dan banyak uang yang nota bene juga para penguasa dan pengusaha. Pengusaha yang memiliki banyak uang seringkali menggunakan kekayaannya untuk menyuap para penyelenggara pemerintahan

${ }^{12}$ Andi W. Syahputra (2000), "Mampukah Kita Membangun Good Public Governance?" dalam Jurnal Transparansi, Jakarta.

${ }^{13}$ Amien Rais (1992), Refleksi Amien Rais: Dari Semut Sampai Gajah, Jakarta: Gema Insani Press, p. 51.

${ }^{14}$ Ibid.p. 51. Jakarta.

${ }^{15}$ Syahrir (1999), “Good Governance di Indonesia Masih Utopia” dalam Jurnal Transparansi,

16 Mardjono Reksodiputro (2000), "Membangun Pondasi Good Governance di Masa Transisi" dalam makalah Diskusi Panel Pada Financial Club Jakarta tidak diterbitkan 
untuk membebaskan atau meringankan hukuman yang dijatuhkan padanya dalam suatu pelanggaran hukum.

\section{Ajaran Agama dan Prinsip Penyelenggaraan Pemerintaban yang Baik}

Dalam kaitannya dengan agama, sejarah kehidupan Rasulullah Muhammad, sebagai pemimpin umat manusia, tercatat bahwa ia telah mengajarkan dan memberikan contoh tentang prinsip-prinsip dasar penyelenggaraan pemerintahan yang baik. Bahkan bukan hanya itu, Rasulullah Muhammad juga telah memberikan contoh tentang kehidupan masyarakat yang hingga kini dapat dijadikan contoh. Prinsip-prinsip dasar tersebut juga sangat tepat untuk diterapkan dalam menata kehidupan masyarakat saat ini demi terwujudnya kesejahteraan bersama.

Prinsip-prinsip dimaksud adalah:

1. Ketauhidan. Ketauhidan ini berarti bahwa hak memerintah merupakan hak Allah, yang memiliki alam semesta, dan pemberi petunjuk kepada seluruh umat manusia. Firman Allah dalam surat al-An'âm, ayat 57, yang artinya “... Menetapkan bukum itu banyalab bak Allah. Dia menerangkan yang sebenamya dan Dia pemberikeputusan yang paling baik ${ }^{*}$. Hukum yang ditetapkan oleh Allah kepada seluruh umat manusia dapat digunakan untuk mengatur kehidupan manusia, baik perorangan maupun bermasyarakat, agar memperoleh kesejahteraan hidup.

2. Keadilan. Keadilan ini harus dengan tolok ukur sesuai dengan norma dan nilai-nilai ajaran Islam atau biasa dikenal dengan istilah "keadilan Ilabiyab". Yaitu keadilan sebagaimana yang pernah dicontohkan oleh Rasulullah Muhammad, baik dalam kehidupan keseharian selaku pribadi, sebagai kepala rumah tangga, maupun sebagai pemimpin masyarakat. Dalam alQur'an keadilan mempunyai berbagai pengertian dan dimensi. Kata 'adala dapat berarti membuat sesuatu menjadi seimbang, sehingga pengertian keadilan adalah menjadi keseimbangan. $\mathrm{Hal}$ ini sebagaimana difirmankan oleh Allah dalam surat al-Infithâr, ayat 7, yang artinya: "Yang telah menciptakan kamu, lalu menyempurnakan kejadianmu, dan menjadikan (susunan tubub)-mu seimbang". 17 Tubuh manusia diciptakan oleh Allah secara seimbang, sehingga manusia dapat berdiri tegak dengan kokoh dan tidak mudah roboh. Selain itu, dengan prinsip keadilan yang berarti keseimbangan ini, manusia memiliki susunan organ dan sistem tubuh yang serba seimbang sehingga dapat berbuat secara maksimal. Dalam surat al- 
Furqân, ayat 67 , Allah berfirman yang artinya: "Dan orang-orang yang apabila membelanjakan (barta), mereka tidak berlebib-lebihan, dan tidak (pula) kikir, dan adalah (pembelanjaan itu) di tengah-tengah antara yang demikian. ${ }^{218}$ Ayat ini merupakan contoh perwujudan sifat adil, yaitu berlaku seimbang. Adil (seimbang) dalam membelanjakan harta berarti tidak membelanjakannya secara berlebihan, tetapi tidak juga berarti kikir apabila harta itu diperlukan untuk dibelanjakan di jalan Allah seperti infâq dan sbadaqab. Sifat adil ini juga bukan untuk kepentingan diri sendiri, tetapi juga bagi kepentingan orang lain. ${ }^{19}$

3. Syura (musyawarah). Prinsip ini berfungsi sebagai acuan yang harus dilakukan oleh para pengambil kebijakan pada setiap pengambilan keputusan yang dilakukan terutama dalam keputusan yang menyangkut kemaslahatan masyarakat. Allah berfirman dalam surat Ali 'Imrân, ayat 159 , yang artinya:

"Maka disebabkan rabmat dariAllab-lab kamu bersikaplemab-lembut terbadap mereka. Sekiranya kamu bersikap keras lagi berhati kasar, tentulab mereka menjaubkan diri dari sekelilingmu. Karena itu maafkanlab mereka, mohonkanlah ampun bagi mereka, dan bermusyawearablab dengan mereka dalam urusan itu. Kemudian apabila kamu telab membulatkan tekad, maka bertaweakkallah kepada Allah. Sesunggubnya Allab itu menyukai orang-orang yang bertaweakkal kepada-Nyan.

Para ahli tafsir sering membahas ayat ini sebagai dasar kehidupan di masyarakat atau kenegaraan sebagai dasar dari musyawarah. Musyawarah oleh para pemikir dianggap sebagai doktrin kemasyarakatan dan kenegaraan Islam karena jelas nasb-nya dalam Al-Qur'an yang diperkuat oleh sunnab atau keteladanan Nabi Muhammad. ${ }^{21}$ Prinsip syûra ini dapat dijalankan jika terdapat kesamaan derajat dan kebebasan. Salah satu ciri esensial dari penyelenggaraan pemerintahan dalam Islam adalah bahwa pemerintah tidak hanya memerintah berdasarkan hukum, tetapi juga harus mempertimbangkan aspirasi yang berkembang di masyarakat karena merupakan keinginan rakyat. ${ }^{22}$

Penyelenggaraan pemerintahan dapat diharapkan menjadi baik, apabila dalam penyelenggaraannya terdapat keseimbangan (balance) antara unsur-unsur penyelenggara pemerintahan dengan lembaga kemasyarakatan yang mengawasi
${ }^{18}$ Ibid. p. 568.
${ }^{19}$ Dawam Rahardjo (2002), Ensiklopedi Al-Qur'an, Jakarta: Paramadina, p. 374.
${ }^{20}$ Departemen Agama RI, op. cit., p. 103.
${ }^{21}$ Dawam Rahardjo, op. cit, pp. 442 dan 444.
${ }^{22}$ Abdul Rashid Moten (1996), Political Science: An Islamic Perspective, terjemahan Munir A. Mu'in dan Widyawati, Jakarta: Pustaka, p. 109. 
dan mengontrol pelaksanaannya. Penyelenggaraan pemerintahan yang baik merupakan persyaratan yang mutlak untuk memperoleh pelayanan keinginan dan aspirasi rakyat.

Dalam proses memahami apa dan bagaimana proses penyelenggaraan negara yang baik dan kerjasama yang bertanggung jawab, kepedulian dan penghormatan terhadap nilai-nilai hak asasi manusia merupakan bagian paling integral. Nilai-nilai tersebut berfungsi sebagai pilar utama bagi upaya pembangunan masyarakat. ${ }^{23}$ Suatu penyelenggaraan pemerintahan yang baik harus mengandalkan rule of law, terutama yang mencakup bidang ekonomi dan politik, penetapan kebijakan yang transparan, pelaksanaan kebijakan yang bertanggung jawab, birokrasi yang berkualitas dan berorientasi pada pelayanan atas kepentingan rakyat. Partisipasi aktif dari rakyat dalam hal ini juga sangat diperlukan.

Tindakan penyelewengan harta negara tidak boleh lagi diasosiasikan dengan istilah penggelapan keuangan negara tetapi harus diartikan sebagai perbuatan korupsi. Tindakan bribary (penyuapan) dan kickbacks (penerimaan komisi secara tidak sah) juga harus diasosiasikan sebagai bagian dari tindak pidana korupsi. Perbuatan lain yang dapat dikatakan sebagai kesewenang-wenangan dari penyelenggara negara adalah bureaucratic corruption, offencies beyond the reach of the law (ke-jabiliyab-an yang tidak terjangkau oleh hukum), dan embezzlement and misapropriation of public funds (penggelapan dan penyalahgunaan dana masyarakat). Walaupun relatif sulit pembuktian dari kejahatan-kejahatan ini dan tingginya tingkat profesionalitas pelakunya, namun penegakan hukum merupakan suatu keharusan untuk dilakukan dalam rangka penyelenggaraan pemerintahan yang baik. ${ }^{24}$

Oleh karena para koruptor dan siluman pembobol keuangan negara berasal dari orang-orang yang memiliki kualitas kecerdasan, profesionalitas, dan kualitas berpikir untuk memecahkan permasalahan-permasalahan bangsa, maka penegakan hukum atas mereka juga harus dilakukan secara profesional. Mereka yang mempunyai kewajiban tetapi menyelewengkannya, tergolong orang yang memiliki kemampuan tetapi tidak bisa melakukan (no action, talk only) karena kecerdasan dan profesionalitasnya tidak mampu menghentikan tindakan kriminal yang menyelimutinya. Paradigma pembangunan bangsa Indonesia yang selama

${ }^{23}$ Emil Salim, op. cit.

24 Dadang Solihin (2000), "Anti Corruption and Good Governance", dalam makalah Diskusi Sekretariat Pengembangan Public Good Govermance Bappenas, Jakarta tidak diterbitkan. 
ini lebih menekankan modernisasi dalam arti pembangunan dan pembaruan infrastruktur masih memerlukan koreksi dan perubahan serius ke arah paradigma yang berorientasi pada pengangkatan martabat manusia sebagai manusia yang berhati nurani, manusia yang sadar akan kemanusiaannya, ${ }^{25}$ dan pengangkatan derajat diri sebagai manusia yang beradab.

\section{E. Penutup}

Dalam upaya penyelenggaraan pemerintahan yang bersih, maka nilai-nilai agama yang memperkuat fungsi dan peran hati nurani merupakan suatu tuntutan mutlak. Nilai-nilai agama dimaksud bukan berupa agama sebagai ilmu tentang nilai-nilai yang dimengerti oleh kecerdasan intelektual dan terhenti pada pemahaman belaka atau memahami agama pada pelaksanaan ritualnya saja, melainkan menjadikan nilai-nilai agama yang sebagai sesuatu yang mampu menjiwai semangat kerja dalam menyelenggarakan pemerintahan. Kualitas sumber daya manusia seperti inilah yang dirasa sangat dibutuhkan untuk dapat mengontrol dan menjalankan roda pemerintahan. Secara ringkas dapat dikatakan bahwa penyelenggara pemerintahan yang baik adalah mereka yang memahami "apa yang harus dilakukan" dan "apa yang tidak boleh dilakukan".

\section{DAFTAR PUSTAKA}

Abdul Rashid Moten (1996), Political Science: An Islamic Perspective, terjemahan Munir A. Mu'in dan Widyawati, Jakarta: Pustaka.

Amien Rais (1992), Refleksi Amien Rais: Dari Semut Sampai Gajah, Jakarta: Gema Insani Press.

Andi W. Syahputra (2000), "Mampukah Kita Membangun Good Public Governance?" dalam Jurnal Transparansi, Jakarta.

Ardiansyah Samsura (2002), Participatory Planning, Good Governance, and Civil Society, Forum Pengembangan Partisipasi Masyarakat (FPPM).

Bagir Manan (1999), "Good Governance Hindarkan Rakyat dari Tindakan Negara yang Merugikan" dalam Jurnal Transparansi, Jakarta.

Dadang Solihin (2000), "Anti Corruption and Good Governance", dalam makalah Diskusi Sekretariat Pengembangan Public Good Governance Bappenas, Jakarta tidak diterbitkan.

${ }^{25}$ Din Syamsuddin (2000), "Pembangunan Berkelanjutan Dalam Peningkatan Keimanan dan Ketaqwaan" dalam Makalab Seminar Pembangunan Hukum Nasional VIII, di Denpasar, Bali. 
"eבreye[? [stpapdsupLL [eun [uाep “e!don

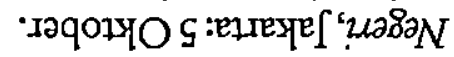

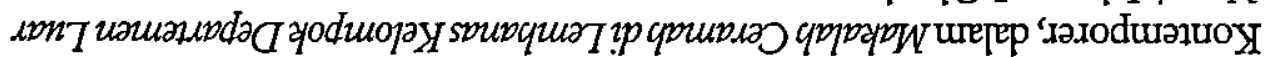

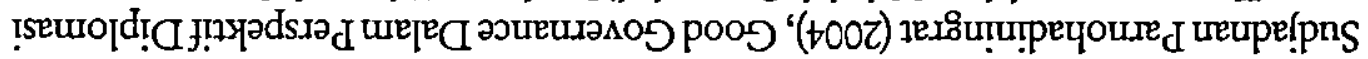
'едRеYе['tsupspdsups I [eun[

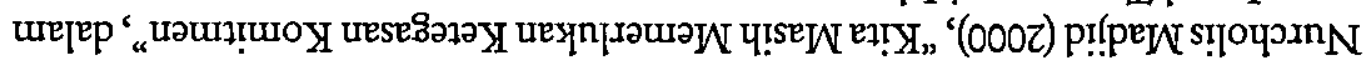



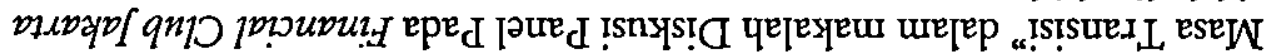

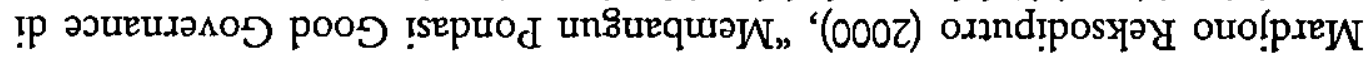

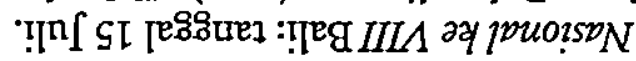

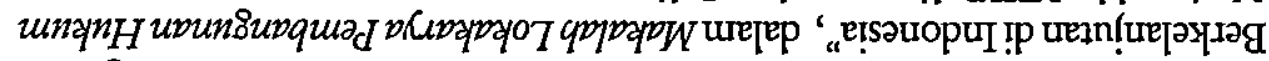

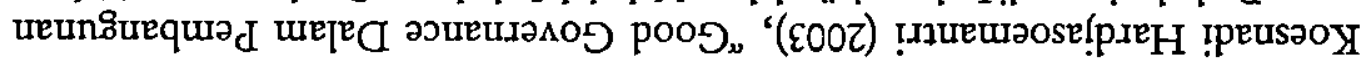

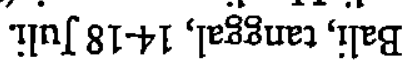

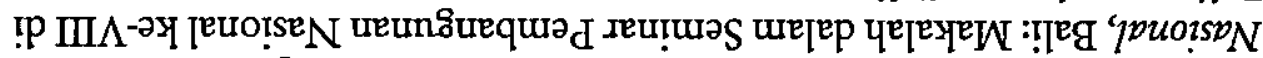

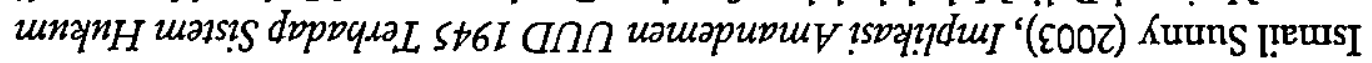
"enreye ("zsupspdsupsL

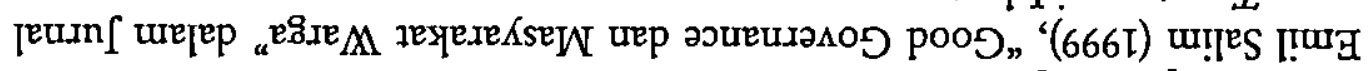
EITEYT [ " sSUDADdsUDsL

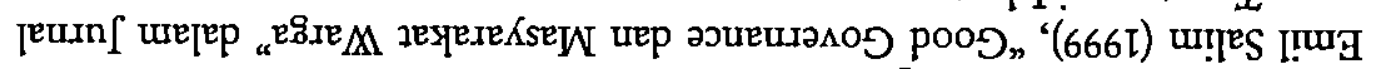

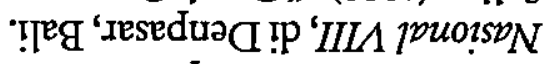

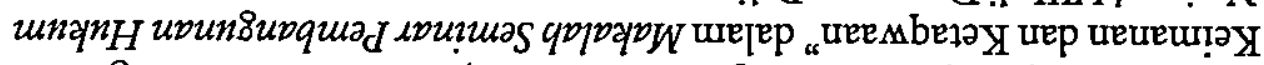

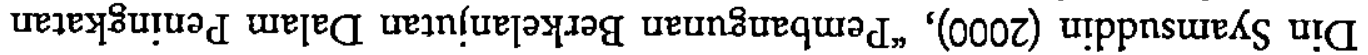

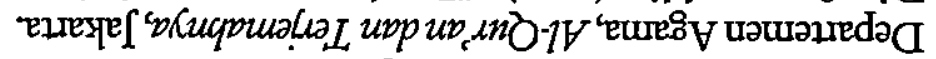

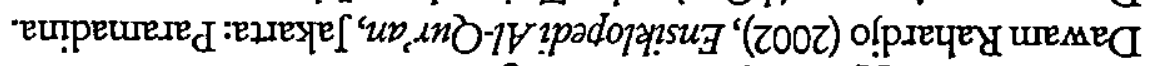

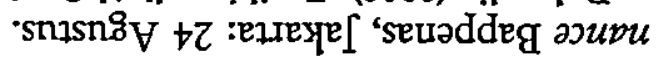



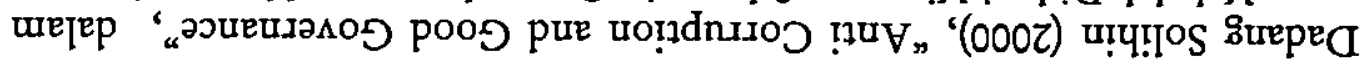

